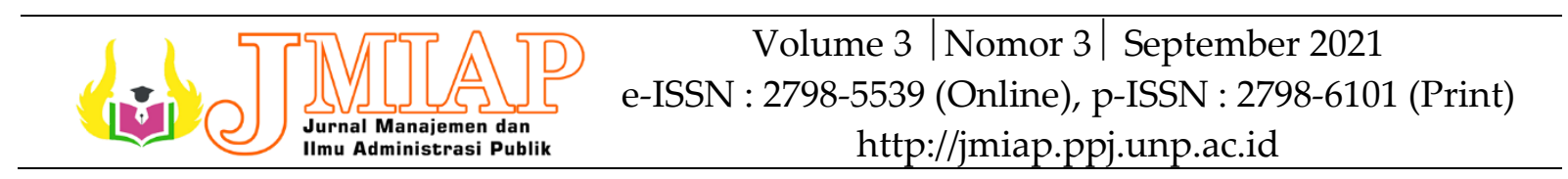

\title{
EFEKTIVITAS KINERJA DINAS PEMADAM KEBAKARAN KOTA PADANG DALAM PENCEGAHAN BAHAYA KEBAKARAN
}

\author{
Suci Rahmadhani ${ }^{1(a)}$, Zikri Alhadi ${ }^{2(b)}$ \\ ${ }^{1,2}$ Jurusan Ilmu Administrasi Negara, Universitas Negeri Padang \\ ${ }^{a)}$ suciirahmadhan@gmail.com, ${ }^{b)}$ the.zikrialhadi@gmail.com
}

\begin{tabular}{l}
\multicolumn{1}{c}{ INFORMASI } \\
ARTIKEL \\
\hline Article History: \\
Dikirim: \\
16-07-2021 \\
Selesai Revisi: \\
08-09-2021 \\
Diterbitkan Online: \\
30-09-2021 \\
\hline
\end{tabular}

Kata Kunci:

Efektivitas, Kinerja Pemadam

Kebakaran

Penelitian ini dilakukan di Dinas Pemadam Kebakaran Kota Padang yang bertujuan untuk mengetahui efektivitas kinerja, hambatan yang menjadi kendala dan mengidentifikasi solusi untuk mengatasi hambatan dalam mencapai kinerja sesuai dengan tujuan, sasaran dan visi misi Dinas Pemadam Kebakaran. Penelitian ini menggunakan metode kualitatif dengan menggunakan purposive sampling. Proses pengumpulan data dilakukan melalui observasi, wawancara, dan studi dokumentasi, sedangkan teknik pengujian validitas data menggunakan triangulasi sumber dengan analisis data seperti pengumpulan data, reduksi data, penyajian data dan penarikan kesimpulan. Hasil penelitian yang dilakukan adalah menjelaskan efektivitas kinerja Dinas Pemadam Kebakaran Kota Padang yang belum optimal, karena masih terdapat kendala seperti: karena kurangnya sarana dan prasarana penanggulangan kebakaran dan penanggulangan bencana, dana penanggulangan bencana manajemen, dan Sumber Daya Manusia (SDM), dapat disimpulkan bahwa efektivitas kinerja Dinas Pemadam Kebakaran Kota Padang belum maksimal dalam mencegah bahaya kebakaran.

Keywords:

Effectiveness, Fire Fighting

Performance

Corresponding Author:

suciirahmadhan@gmail.com

DOI:

https://doi.org/10.24036/jmiap.v3i3.277

\section{ABSTRACT}

This research was conducted at the Fire Department of Padang City which aims to determine the effectiveness of performance, the obstacles that become obstacles and identify solutions to overcome obstacles in achieving performance in accordance with the objectives, targets and vision and mission of the Fire Department.This study uses a qualitative method using purposive sampling. The data collection process is carried out through observation, interviews, and documentation studies, while the data validity testing technique uses source triangulation with data analysis such as data collection, data reduction, data presentation and drawing conclusions. The results of the research carried out were to explain the effectiveness of the performance of the Padang City Fire Service is not optimal, because there are still obstacles such as: due to lack of facilities and infrastructure for fire prevention and disaster prevention, funds for disaster management, and Human Resources (HR), it can be concluded that The effectiveness performance of the Padang City Fire Department has not been maximized in preventing fire hazards. 


\section{PENDAHULUAN}

Membicarakan mengenai kebakaran merupakan suatu kejadian yang sering terjadi apabila adanya percampuran zat kimia serta bereaksi secara berlebihan dengan oksigen menimbulkan panas, api, cahaya asap, uap air, dan zat lainnya seperti karbon manoksida, karbon dioksida. (Furness dan Muckett, 2017: 120-122). Ada tiga faktor mendasar yang menyebabkan terjadinya kebakaran, yaitu: bahan bakar minyak, oksigen dan panas. bahan bakar,oksigen dan panas. Sedangkan terdapat campur tangan penyebab kebakaran seperti: Ulah tangan manusia, Penyalaan sendiri dan Peristiwa alam.

Pemadam Kebakaran ialah suatu organisasi yang mempunyai tugas dalam bidang melayani, melindungi masyarakat baik seperti pertolongan aksi untuk tindakan pemadaman dan pencegahan kebakaran. Sebelum kebakaran terjadi, perlu melakukan strategi yang baik yaitu: Tahapan strategis tersebut digunakan sebagai upaya pengendalian resiko kebakaran dengan menekan tingkat kemungkinan dan tingkat keparahan resiko.

Upaya pemadam kebakaran sering dilaksanakan secara bersama- sama oleh warga meggunakan alat secukupnya. Persolan yang ditemui sepanjang ini ialah: kelalaian atas waktu hadir satuan pemadam kebakaran. Hal ini terjadi tiga hal yaitu:

1. Rendahnya sikap siap sedia petugas, kedua.

2. Macetnya lalu lintas dijalan menuju lokasi kejadian.

3. Tertinggalnya informasi yang diperoleh personel menggunakan call center 113 dari masyarakat mendapat. musibah itu.

Semboyan "Pantang Pulang Sebelum Padam" yang merupakan jati diri pemadam kebakaran. Melalui semboyan yang dijadikan patokan, petugas kebakaran tidak mementingkan diri sendiri, kerabat, maupun keluarga namun lebih memprioritaskan akan keamanan masyarakat dalam menghadapi musibah. Saat menjalankan pekerjaannya, aparat kebakaran berusaha segera tuntas dan mengurangi akan adanya korban jiwa.

Fungsi Dinas Kebakaran sudah termuat dalam peraturan Walikota Padang Nomor 70 Tahun 2009 pada pasal 7 ayat 2 di bidang pencegahan, yang berbunyi:

a) Menyusun rumusan kebijakan pencegahan resiko kebakaran; b) Melakukan pengaturan pelaksanaan tugas pencegahan resiko kebakaran;

c) Melakukan evaluasi dan penyusunan laporan tugas pencegahan resiko kebakaran;

d) Melakukan pelaksanaan administrasi seksi;

e) Menjalankan kewajiban pada dinas lain yang diamanahkan dari ketua sebanding dengan tugas dan fungsinya.

Berdasarkan hasil wawancara dengan bapak syahrul mengatakan:

..."Dinas Pemadam Kebakaran (Damkar) Kota Padang hanya memiliki 16 unit mobil pemadam kebakaran dan 116 orang tenaga pemadam kebakaran, sarana dan prasarana yang ada tersebut tidak sebanding dengan intensitas bencana yang melanda. Seharusnya Kota Padang harus memiliki personil pemadam kebakaran sekitar 150 orang. Namun saat ini hanya ada 116 orang. Dan untuk pekerja yang turun kelapangan hanya sekitar 50 orang,dan belum tentu 50 orang tersebut selalu ada pada saat kebakaran yang terjadi. Tentunya dengan keterbatan personil pihak damkar harus menambah jam kerja atau pergantian sift jika terjadinya kebakaran secara tiba-tiba.

Tabel 1. Jumlah Kejadian Kebakaran Tahun 2019 Berdasarkan Penyebab Kebakaran

\begin{tabular}{|l|c|c|c|c|}
\hline Bulan & Kompor & $\begin{array}{c}\text { Lampu } \\
\text { Minyak }\end{array}$ & Listrik & Lain-Lain \\
\hline Januari & 2 & 0 & 18 & 14 \\
\hline Februari & 4 & 0 & 18 & 11 \\
\hline Maret & 3 & 2 & 7 & 10 \\
\hline April & 2 & 0 & 11 & 10 \\
\hdashline Mei & 0 & 0 & 11 & 29 \\
\hline Juni & 2 & 0 & 7 & 21 \\
\hline
\end{tabular}

Sumber: Dinas Pemadam Kebakaran Kota Padang

Tabel menunjukkan bahwa penyebab terjadinya kebakaran paling banyak terjadi di kota padang yaitu disebabkan oleh listrik, dibandingkan pada penyebab kebakaran lainnya. Kasus kebakaran yang terjadi di Kota Padang yang paling sering terjadi adalah kebakaran bangunan perumahan, berikut penjelasan mengenai kasus kebakaran dalam bentuk yaitu: 
Tabel 2. Rekapitulasi Kejadian Bencana Kebakaran Tahun 2019 Januari-Juni

\begin{tabular}{|l|c|c|c|c|c|c|c|}
\hline Bulan & $\begin{array}{c}\text { Bangunan } \\
\text { Perumahan }\end{array}$ & $\begin{array}{c}\text { Bangunan } \\
\text { Umum }\end{array}$ & $\begin{array}{c}\text { Bangunan } \\
\text { Industri }\end{array}$ & Kendaraan & Hutan & Evakuasi & Lain-lain \\
\hline Januari & 8 & 0 & 6 & 2 & 1 & 10 & 8 \\
\hline Februari & 16 & 0 & 3 & 0 & 3 & 6 & 5 \\
\hline Maret & 9 & 0 & 1 & 2 & 0 & 6 & 8 \\
\hline April & 14 & 0 & 0 & 0 & 1 & 10 & 8 \\
\hline Mei & 9 & 0 & 3 & 2 & 3 & 8 & 15 \\
\hline Juni & 11 & 0 & 0 & 1 & 1 & 10 & 2 \\
\hline
\end{tabular}

Sumber: Dinas Pemadam Kebakaran Kota Padang

Bagi dinas pemadam kebakaran disamping tindakan penanggulangan pada saat terjadi kebakaran juga tak kalah pentingnya tindakan pencegahan terhadap bahaya kebakaran sebelum terjadi kebakaran.

Pada saat kejadian, aparat pemadam kebakaran sangat di wajibkan kritis dilingkungan setempat. Hal ini ditandai dengan aba-aba yang arahkan oleh rekan dalam suatu kelompok mengeluarkan dan mempertemukan antar selang ke nozzle (alat semprot), perputaran dan pelepasan aliran air, sampai deportasi alat- alat ke dalam carrier. Petugas pemadam kebakaran wajib memahami situasi dan putaran angin saat berada di gedung agar mengtahui hawa panas yang keluar, asap maupun zat lain bersifat berbahaya di tempat kejadian. Dalam peristiwa kebakaran terjadi, aparat pamadam kebakaran harus ada sifat ingin tahu dan bersedia memberi bantuan sementara seperti pengobatan kepada korban bencana sampai ambulan tiba di saat lebih lanjut.

Untuk melakukan hal tersebut Oleh karena petugas pemadam kebakaran memerlukan kekuatan dan keterampilan dengan cara mengadakan training mengatasi persoalan pelatihan fisik dan hal yang berbahaya. Dengan tujuan agar petugas tanggap dan tangkas terhadap kejadian yang terjadi secara mendadak. Berdasarkan hasil wawancara yang dilakukan peneliti dengan kasi operasional Damkar Kota Padang yaitu Bapak Syahrul menyatakan:

...."penyebab kebakaran tersebut terdapat 3 yaitu: yang pertama, faktor manusia, faktor manusia itu sendiri tedapat 4, yaitu mendekatkan benda mudah terbakar dari sumber panas, mematikan api dengan sarana yang tidak lengkap. kelalalian.kelalaian itu sendiri yang paling banyak terjadi kebakaran, dan yang kedua yaitu penyalaan sendiri misalnya: timbunan sampah,serta pada penyimpanan bahan mudah terbakar. Dan yang ketiga yaitu peristiwa alam, seperti gempa bumi, gunung meletus dan kilatan petir. (wawancara 16 Maret 2020).

Adapun upaya yang dilakukan oleh pemerintah Damkar Kota Padang dalam mengatasi atau menanggulangi bencana kebakaran ini adalah dengan cara melakukan tindakan preventif (pencegahan), tindakan Reprensif (pada saat terjadinya kebakaran), tindakan Rehabilitative.

Pemerintah Damkar Kota Padang melakukan tindakan preventif (pencegahan) itu sendiri kepada masyarakat yaitu dengan melakukan sosialisasi tentang bagaimana mencegah terjadinya kebakaran. Menurut Bapak Syahrul Kasi Operasional menyatakan:

..."Dinas Pemadam Kebakaran terus melakukan sosialisasi kepada masyarakat,kemudian patroli bersama memantau lokasi-lokasi dimana terdapat titi api, kemudian call center selalu stanby, dan pengecekan setiap pos-pos damkar. Tetapi hal tersebut masih belum efektif. Karena kurangnya partisipasi dari masyarakat yang mana masnyarakat masih menggangap sosialisasi siaga bencana tidak terlalu penting. Sehingga terjadi penyebab tinggi nya angka kebakaran itu sendiri.

Masyarakat menjadi komponen utama untuk merasakan kejadian, oleh sebab itu diperlukan sikap kemandirian karena menghadapi kejadian dibutuhkan kewaspadaan,pengalaman dan keahlian pada diri masyarakat. (Martanto., dkk, 2017).

Pencegahan dan Penanggulangan kebakaran salah satu bertujuan untuk menghindari, menyiapkan, serta mematikan akibat kebakaran, sehingga penanggulangan kebakaran ialah Tindakan untuk persiapan sebelum bencana tersebut terjadi. Cara yang bisa dilakukan dalam Damkar memiliki kewajiban dalam penaggulangan dan pencegahan kebakaran yaitu dengan cara membagi informasi kepada masyarakat, terhadap dampak, akibat , serta cara dalam menangani apabila kebakaran terjadi.

Dapat disimpulkan bahwa dari hasil wawancara penulis dengan salah satu Kasi operasional Dinas Pemadam Kebakaran Kota Padang adalah apakah bencana kebakaran di kota padang terjadi karena belum optimalnya peran Dinas Pemadam Kebakaran menjalankan 
pekerjaan yang diamanahkan untuk pencegahan dan penanggulangan kebakaran. Terkait dengan permasalahan yang sudah di uraikan sehingga adanya ketertarikan penulis melaksanakan penelitian yaitu:"Efektivitas Kinerja Dinas Pemadam Kebakaran Kota Padang dalam Pencegahan Bahaya Kebakaran".

\section{METODE PENELITIAN}

Lokasi untuk penelitian ini berada di Dinas Pemadam Kebakaran dan memakai penelitian kualitatif deskriptif. Penelitian memfokuskan pada pada 2 pokok pembahasan yaitu: 1) Efektivitas Efektivitas Dinas Pemadam Kebakaran Kota Padang dalam Pencegahan Bahaya Kebakaran. Dalam hal ini membahas untuk menganalisis sejauh mana efektivitas Dinas Pemadam Kebakaran Kota Padang dalam Pencegahan Bahaya Kebakaran. 2) Kendala dan hambatan Dinas Pemadam Kebakaran Kota Padang dalam Pencegahan Bahaya Kebakaran. Pada bagian ini menjelaskan apa-apa saja kendala ekternal dan internal serta hambatan yang mempengaruhi dalam mencegah bahaya kebakaran.

Penentuan informan diambil dengan teknik purposive sampling yaitu: suatu teknik bagi informan dalam memberikan informasi. Uji keabsahan data dalam penelitian ini triangulasi sumber seperti: reduksi data, penyajian data serta penarikan kesimpulan. Kerangka pikir penelitian:

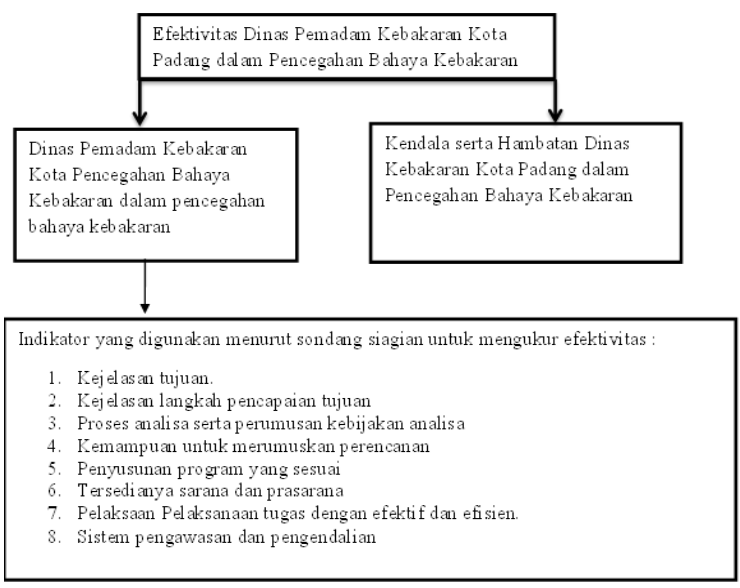

Gambar 1. Kerangka Konseptual

\section{HASIL DAN PEMBAHASAN}

Pemadam kebakaran merupakan singkatan dari Damkar. Dinas pemadam kebakaran ialah salah satu instansi pemerintah yang diamanahkan untuk melakukan pekerjaan dalam menangani permasalahan kebakaran seperti unsur penyelamatan. Dalam hal ini, pencegahan bencana kebakaran yang dilaksanakan instansi pemerintah tersebut ialah tindakan preventif, tindakan represive dan tindakan rehabilitative. Pencegahan (preventif) bencana kebakaran dimaksudkan agar dapat dimana kita melakukan antisipasi sebelum bencana. Dengan pentingnya pencegahan tersebut peneliti meneliti mengenai Efektivitas Kinerja Dinas Pemadam Kebakaran Kota Padang pencegahan bahaya kebakaran. Untuk mengetahui efektif atau tidaknya pencegahan bencana bahaya kebakaran tersebut dapat dilihat dai indikator.

Berdasarkan hasil temuan penelitian yang telah dilakukan sebelumnya, peneliti akan menganalisa data yang diperoleh. Baik melalui literature maupun studi dilapangan yang dilakukan mengenai Efektivitas Kinerja Dinas Pemadam Kebakaran Kota Padang dalam Pencegahan Bahaya Kebakaran.

\section{Efektivitas Kinerja Dinas Pemadam Kebakaran Kota Padang dalam Pencegahan Bahaya Kebakaran}

Berdasarkan peneliti yang dilakukan dilapangan ada beberapa temuan yang peneliti dapatkan dilapangan yaitu diantaranya dilihat dari indikator efektivitas,merujuk pada pendapat yang dikemukan oleh Sondang (1983: 32-35) yaitu:

1) Kejelasan tujuan yang hendak dicapai

Efektivitas Kinerja Dinas Pemadam Kebakaran Kota Padang yang dilakukan Damkar dapat dilihat dari sejauh mana tujuan kegiatan atau program dapat mencapai sasaran yang ditentukan sebelumnya. Sehingga tujuan, target maupun sasaran dikatakan berhasil, selain itu jika suatu kegiatan tidak memenuhi target maka tidak berhasil.

Berdasarkan hasil penelitian yang dilakukann dilapangan bahwa belum efektifnya penanggulangan dan pencegahan bencana kebakaran di kota padang. Berdasarkan faktor penghambat yang dihadapi oleh Dinas Pemadam Kebakaran Kota Padang (DAMKAR) yaitu masih kekurangan personil dalam proses penanggulangan dan pencegahan kebakaran, apalagi ketika terjadinya bencana kebakaran di beberapa titik di kota padang dan lokasi tersebut cukup berjauhan. Dan juga sarana prasarana dalam melakukan pencegahan juga belum memadai dalam penanggulangan dan pencegahan, maka hal tersebut dianggap kurang efektifnya pencegahan bencana 
kebakaran yang dilakukan oleh Damkar Kota Padang.

2) Proses analisa dan perumusan kebijakan yang mantap

Keadaan ini berhubungan dengan kebijakan yang dilaksanakan terhadap tujuan yang hendak dicapai dan strategi yang telah ditetapkan, artinya kebijakan harus mampu menjebatani tujuan-tujuan dengan usaha-usaha pelaksanaan kegiatan operasional.

Berdasarkan hasil temuan penelitian bahwa proses analisa dan perumusan kebijakan telah dilakukan Damkar Kota padang dengan melakukan strategi Karena dalam strategi tindakan pencegahan harus rutin mengadakan sosialiasi tentang bahaya kebakaran. Dan program ini terhenti karena faktor anggaran,dan untuk saat ini faktornya karena lagi pandemi. Dalam strategi selanjutnya dalam setahun harus ada pemeriksan sarana sistem proteksi kebakaran (sapras) itu sendiri guna menimalisir kebakaran pada bangunan gedung.

3) Kemampuan untuk membuat rencana yang mantap

Dari sejauh mana efektivitas perencanaan yang matang, dapat dilihat (a) Memprediksi keadaan pada saat ini (b) membuat tindakan dalam menghadapi era globalisasi yang tidak menentu (c) memperkuat elemen pemosisian di masa depan (d) Mengetahui kendala yang akan muncul di organisasi dan (e) Melihat kondisi disekitaran.

Hasil temuan penelitian di atas menjelaskan bahwa dalam kemampuan untuk merumuskan perencanaan yang matang. Faktor penyebab nya karena masih kurangnya tenaga ahli yang berpengalaman dan kurangnya pelatihan karena dalam hal ini sangat dibutuhkan skill yang mendalam sehingga dapat memprediksi/memperkirakan bencana kebakaran yang melanda pada bangunan gedung tersebut.

4) Penyusunan program yang tepat

Rencana yang baik perlu diperjelaskan dalam mengimplementasikan rencana yang tepat, karena jika tidak mempunyai petunjuk untuk bekerja maupun bertindak.

Hasil penelitian ini mengidentifikasi untuk melakukan penyusunan program yang tepat program yang tepat disini Damkar kota Padang menyusun program yang diberi nama Sapras (sistem proteksi kebakaran) yang merupakan perlengkapan berguna dalam sistem perlindungan/pengamanan bangunan gedung dari kebakaran yang bangun pada bangunan gedung. Sapras yang terdapat digedung juga dapat dikategorikan tidak berfungsi dengan baik melainkan juga ada yang hanya terpasang saja tapi alat tersebut tidak berfungsi/tidak dapat digunakan.

5) Tersedianya sarana dan prasarana

Kelengkapan infrastruktur merupakan salah satu pengukur untuk menentukan efektivitas dengan cara memiliki kemampuan dalam melakukan kegaiatan bermanfaat. Berdasarkan hasil temuan penelitian bahwa dalam ketersediaan sarana dan prasarana ini terdapat pada bangunan gedung yang mana pada bangunan gedung ini sarana atau perlatan pemadam kebakaran yang harus ada didalam gedung, misalnya alat pemadam api ringan (sering disebut apar) atau istilah lain (fire extinguisher), selanjutnya yaitu sistem selang air bertekanan (hydrant sytem) dan sistem pemercik api otomatis (sprinkler sytem) semua sarana dan prasarana harus dicek setiap sebulan sekali berfungsi atau tidaknya sarana alat pemadam kebakaran itu sendiri.

6) Pelaksanaan tugas secara efektif dan efesien

Sasaran yang jelas, jalan keluar yang tepat tahap bernilai, kegiatan yang matang, ketepatan rencana, serta kemampuan memnfaatkan sarana dan prasarana yang terbatas harus diperhatikan dalam operasional yang efektif dan berdaya guna.

Pelaksanaan tugas secara efektif dan efisien ini mengacu pada perda no 16 tahun 2016 yang mana damkar kota padang sudah membentuk suatu bidang pencegahan dan pengujian yang tupoksinya ada melakukan tindakan preventif yang bidang memiliki tiga seksi yaitu 1. Seksi pencegahan 2 seksi pengujian dan terkahir seksi pengawasan. Serta dalam efektivitas pencegahan bahaya kebakaran itu sendiri sudah sesuai pada Peraturan Walikota Peraturan Walikota Padang Nomor 70 Tahun 2016 mengnai penjabaran tupoksi Dinas Pemadam Kebakaran pasal 7 ayat (2) bidang pencegahan yaitu:

a) Menyusun rumusan kebijakan pencegahan resiko kebakaran;

b) Melakukan pengaturan pelaksanaan tugas pencegahan resiko kebakaran; 
c) Melakukan evaluasi dan penyusunan laporan tugas pencegahan resiko kebakaran;

d) Melakukan pelaksanaan administrasi seksi;

e) Menyelesaikan tugas lain yang diamanahkan dari pimpinan kepada bawahan sesuai dengan tugas masingmasing.

7) Sistem pengawasan dan pengendalian yang bersifat mendidik:

(a) Pengendalian dan penanganan memfokuskan pada kegiatan bersifat preventif dan represif (b) Tidak mencari kesalahan orang lain melainkan untuk memyempurnakan aturan kerja dalam organisasi (c) Apabila terjadi penyelewengan maka diperlukan prilaku korektif untuk mengatasinya. (d) Untuk melakukan pengawasan dan pengendalian harus sesuai dengan metode tata cara kerja maupun hasil prestasi yang sudah diketahui secara baik. (e) Pengendalian dan penanganan memiliki sifat edukatif dan objective maka tidak mungkin ada prilaku ketidaksiplinan.

Hasil penelitian ini menjelaskan bahwasannya dalam sistem pengawasan ini Damkar Kota Padang mulai mempersiapkan Komandam regu pada tiap tiap individu yang akan terjun ke lokasi pada saat terjadinya kebakaran.

Kendala yang Dihadapi oleh Damkar Kota Padang dalam Melakukan Pencegahan Bahaya Kebakaran

1) Kendala internal

Kendala internal ini berasal dari dalam organisasi itu sendiri. Dalam pencegahan bahaya kebakaran tentu ada kendala yang dihadapi oleh Dinas Pemadam Kebakaran Kota Padang. Berdasarkan hasil temuan penelitan kendala internal yang dialami oleh Damkar Kota padang yakni: Masih kekurangan peralatan; Personil yang terlatih terhadap bencana kebakaran ini masih jauh dari harapan, yang mana personil masih minim skiil apalagi yang masih tamatan SMA; dan Anggaran yang dibutuhkan Damkar juga masih kurang.

2) Kendala Eksternal

Dalam pencegahan bahaya kebakaran kendala yang dihadapi tidak selalu bersumber di dalam organiasi saja melainkan luar organisasi dihadapi pula oleh Damkar Kota Padang yaitu kurangnya tingkat kesadaraan masyarakat untuk memahami potensi bencana kebakaran. Dalam hal ini pemahaman dan keingintahuan masyarakat yang besar dapat meningkatkan keikutsertaan masyarakat berperan aktif terhadap penyelenggaraan penanggulangan dan pencegahan baik secara pra bencana,saat bencana dan pasca bencana. Berdasarkan hasil temuan penelitan kendala ekternal yang terdapat pada damkar kota padang yaitu: Kurangnya tingkat kesadaran masyarakat dalam memahami potensi bencana kebakaran; Sulit akses masuk mobil pemadam kebakaran (gang sempit pada permukiman penduduk); Belum mempunyai sistem proteksi (hidran) harus mempunyai supply air, apabila kebakaran jauh dari jangkauan air; dan Belum pernah melakukan sosialiasi ke masyarakat.

\section{Solusi yang dilakukan Dinas Pemadam Kebakaran Kota Padang dalam Pencegahan Bahaya Kebakaran}

Dari berbagai kendala yang dihadapi oleh Damkar Kota Padang dalam melakukan pencegahan bahaya kebakaran,baik itu dari kendala internal (dalam) dan kendala ekternal (luar) organisasi tersebut. Tentu ada solusi yang dilakukan untuk menghadapi kendala-kendala tersebut. Ada tiga tahap dalam menghadapi bencana yaitu: pencegahan,aksi ketika kejadian bencana kebakaran dan pasca bencana. Hal utama terletak pada pencegahan,dimana kita melakukan antisipasi sebelum bencana. Solusi yang dilakukan Dinas Pemadam Kebakaran Kota Padang dalam Pencegahan Bahaya Kebakaran yakni:

a) Balaker (barisan relawan kebakaran) mengingat wilayah kota padang yang luas, Damkar Kota Padang membentuk Balaker yang membetuk kelompok advance yang bertugas mematikan sijago merah sebelum kedatangan Damkar dilokasi sehingga tidak menyebabkan api membesar;

b) Inovasi (gang sempit) pipa penyalur mobil sulit masuk, yang mana maksudnya disini pipa penyalur merupakan kawasan yang padat penduduk, maka harus ada inovasi sehingga wilayah tersebut yang menjadi kebakaran jadi mobil tidak perlu masuk untuk kedalam jadi air diambil melalui pipa penyalur itu sendiri,tanpa adanya pipa penyalur tersebut tindakan kebakaran menjadi kesulitan jika terjadi dikawasan padat penduduk.

Solusi selanjutnya yaitu: 
a) Memberikan penuluhan atau pelatihan baik kepada masyarakat maupun pengelola gedung;

b) Menyediakan alat pemadam kebakaran baik peralatan modern seperti APAR, hydrant, Spkinkler sytem, maupun peralatan tradisional lainnya seperti karung goni dan kain.

\section{PENUTUP}

Kinerja Dinas Pemadam Kebakaran Kota Padang masih belum berjalan maksimal. Hal ini dapat diketahui dari indikator efektivitas karena belum tercapinya target-target yang ditetapkan,karena kekurangan sarana dan prasarana penanggulangan dan pencegahan bencana bahaya kebakaran, dana penanggulangan bencana, dan Sumber Daya Manusia (SDM), masih ditemukan banyak masalah yang menyebabkan tidak terwujudnya visi, misi, tujuan dan terget yang telah ditetapkan.

Kendala internal yang dihadapi oleh damkar kota padang yaitu masih kurangnya peralatan yang digunakan masih minim, personil yang terlatih terhadap bencana kebakaran ini masih jauh dari harapan, yang mana personil masih minim skiil apalagi yang masih tamatan SMA.dan kekurangan anggaran. Sedangkan kendala ekternal yang dihadapi oleh damkar kota padang adalah kurangnya tingkat kesadaran masyarakat dalam memahami potensi bencana kebakaran. sulit akses masuk mobil pemadam kebakaran (gang sempit pada permukiman penduduk). belum mempunyai sistem proteksi (hidran) harus mempunyai supply air, apabila kebakaran jauh dari jangkuan air atau kejadian lainnya.

Solusi yang dilakukan Dinas Pemadam Kebakaran Kota Padang dalam Pencegahan Bahaya Kebakaran yakni: Balaker (barisan relawan kebakaran) mengingat wilayah kota padang yang luas, Damkar Kota Padang membentuk Balaker yang membetuk kelompok advance yang bertugas mematikan sijago merah sebelum kedatangan Damkar dilokasi sehingga tidak menyebabkan api membesar; Inovasi (gang sempit) pipa penyalur mobil sulit masuk, yang mana maksudnya disini pipa penyalur merupakan kawasan yang padat penduduk, maka harus ada inovasi sehingga wilayah tersebut yang menjadi kebakaran jadi mobil tidak perlu masuk untuk kedalam jadi air diambil melalui pipa penyalur itu sendiri,tanpa adanya pipa penyalur tersebut tindakan kebakaran menjadi kesulitan jika terjadi dikawasan padat penduduk. Solusi selanjutnya yaitu: Memberikan penuluhan atau pelatihan baik kepada masyarakat maupun pengelola gedung; Menyediakan alat pemadam kebakaran baik peralatan modern seperti APAR, hydrant, Spkinkler sytem, maupun peralatan tradisional lainnya seperti karung goni dan kain.

\section{DAFTAR PUSTAKA}

Furness dan Muckett. (2017). Introduction To Fire Safety Management. Oxford. Ekselfierd Ltd, XXXX.

Moeheriono. (2011). Perencanaan, Aplikasi dan Pengembangan Indikator Kinerja Utama . PT. Grafindo Persada. Surabaya.

Ramli. (2010). Petunjuk Praktis Manajemen Kebakaran (Fire Management). Dian Rakyat. Jakarta.

Sinambela, L. (2012). Kinerja Pegawai, Teori Pengukuran dan Implikasi.

Sondang, P. D. P. S. (1983). Filsafat Administrasi. In Pemikiran Islam di Malaysia: Sejarah dan Aliran. Bumi Aksara. Jakarata.

Wiarto, Giri. (2017). Tanggap Darurat Bencana Alam. Yogyakarta: Gosyen Publishing.

Yani. (2012). Manajemen Sumber Daya Manusia. Jakarta: Mitra Wacan Media.

Suryadi, Hery, dan Yudhi Kuswandi. (2014). Analisis Pelaksanaan Tugas Dinas Pemadam Kebakaran Kota Pekanbaru Pada Tahun 2008-2012. Jurnal Online Mahasiswa Fakultas Ilmu Sosial dan Ilmu Politik Universitas Riau (Vol.1, hal. 1-15).

Zikri Alhadi, (2014). Kesiapan Jalur dan Lokasi Evakuasi Publik Menghadapi Resiko Bencana Gempa dan Tsunami Di Kota Padang. Jurnal Humanus (Vol. XIII Nomor 1). 
Suci Rahmadhani, Zikri Alhadi I Efektivitas Kinerja Dinas Pemadam Kebakaran Kota Padang dalam Pencegahan Bahaya Kebakaran

Peraturan Mentri Pekerjaan Umum No. 26/PRT/M/2008 tentang Persyaratan Teknis Sistem Proteksi Pada Bangunan Gedung dan Lingkungan.

Peraturan Menteri Negara Pekerjaan Umum Nomor 20/PRT/2009 tentang Pedoman Teknis Manajemen dan Penanggulangan Kebakaran di Perkotaan.
Peraturan Daerah Kota Padang Nomor 6 Tahun 2016 tentang Dasar Hukum Pembentukan Dinas Pemadam Kebakaran.

Peraturan Walikota Padang Nomor 70 Tahun 2016 tentang Penjabaran Tugas Pokok dan Fungsi Dinas Pemadam Kebakaran. 